\title{
Advances in high-throughput methods for the identification of virus receptors
}

\author{
Sarah V. Barrass ${ }^{1}$ (i) $\cdot$ Sarah J. Butcher ${ }^{1}$ (1)
}

Received: 6 June 2019 / Accepted: 2 December 2019 / Published online: 21 December 2019

(c) The Author(s) 2019

\begin{abstract}
Viruses have evolved many mechanisms to invade host cells and establish successful infections. The interaction between viral attachment proteins and host cell receptors is the first and decisive step in establishing such infections, initiating virus entry into the host cells. Therefore, the identification of host receptors is fundamental in understanding pathogenesis and tissue tropism. Furthermore, receptor identification can inform the development of antivirals, vaccines, and diagnostic technologies, which have a substantial impact on human health. Nevertheless, due to the complex nature of virus entry, the redundancy in receptor usage, and the limitations in current identification methods, many host receptors remain elusive. Recent advances in targeted gene perturbation, high-throughput screening, and mass spectrometry have facilitated the discovery of virus receptors in recent years. In this review, we compare the current methods used within the field to identify virus receptors, focussing on genomic- and interactome-based approaches.
\end{abstract}

Keywords Receptor identification · Mass spectrometry $\cdot$ Genome perturbation $\cdot$ Virus

\section{Introduction}

Viruses are intercellular pathogens dependent on their host's cellular machinery for replication. To infect the host, the virus must first gain entry into the cell, breaching the cell's primary barrier to infection, the cell membrane. The entry process is initiated by the interaction between viral attachment proteins and host cell surface structures. Host cell surface structures can act as either attachment factors, which localise the virus at the cell surface, or entry receptors, which actively initiate virus entry (reviewed in [1]). In the literature, receptors are referred to as molecules that can mediate attachment, entry into the endocytic compartment, entry from the endocytic membrane into the cytosol,

Edited by Volkhard A. J. Kempf.

Sarah V. Barrass

Sarah.Barrass@helsinki.fi

Sarah J. Butcher

Sarah.Butcher@helsinki.fi

1 Faculty of Biological and Environmental Sciences, Molecular and Integrative Bioscience Research Programme and Helsinki Institute of Life Sciences, Institute of Biotechnology, University of Helsinki, P.O. Box 56, 00014 Helsinki, Finland and uncoating. Uncoating leads to the release of the viral genome from its protective capsid structure, and proceeds in a stepwise fashion under the guidance of cellular cues [2]. In this review, we use a narrower definition of a receptor, referring to those molecules that are actively involved in the entry of viruses into eukaryotic cells.

Interactions with host attachment factors are often electrostatic and non-specific, only acting to localise the viral particle before the recruitment of specific receptors required for entry. Often, these are low-affinity interactions and utilise common glycolipids and glycoproteins found on host cells, such as heparan sulphate used by tick-borne encephalitis virus [3-5]. Additionally, viruses have been shown to use different attachment factors depending on the model system used, possibly reflecting wide host and tissue tropism [3].

After the virus is concentrated onto the host cells, binding to specific entry receptors can occur. These receptors actively facilitate host cell entry by one of two processes: receptor-mediated endocytosis or receptor-mediated activation of signalling pathways, leading to virus internalisation (reviewed in [6]). Some viruses only require one receptor to facilitate entry into host cells, such as sialic acid for influenza A virus [7]. However, some viruses require co-receptors on the same cell or different receptors on different cell types to initiate infection. This is observed for measles virus, 
which uses the signalling lymphocyte-activation molecule and nectin- 4 as receptors, and hepatitis $\mathrm{C}$ virus using tetraspanin, occludin, human scavenger receptor class $\mathrm{B}$ type I, and claudin-1 [8-13]. These receptors may be required for infection to occur, or partially redundant only assisting with viral infection. For hepatitis C, tetraspanin, occluding, and claudin-1 have been shown to be crucial for virus entry, whereas human scavenger receptor class B type I has been shown to be partially redundant [14].

Regardless of the method utilised by the virus for cell entry, virus-receptor interactions are pivotal in establishing infection. Therefore, understanding viral-receptor interactions is of significant importance from a cell biology perspective, allowing us to expand our knowledge of viral life cycles, tissue and species tropism, and pathogenesis. Furthermore, these insights can lead to the development of new antivirals, vaccines, and diagnostic technologies, combating pathogenic human viruses.

A wide range of methods have been applied over the years for the identification of viral receptors, with early studies (reviewed in [15]) using monoclonal and anti-idiotypic antibodies, solid-phase assays, and affinity purification with receptor antibodies [16-19]. However, over the last 2 decades, the field has advanced significantly due to the development of targeted gene perturbation, high-throughput screening (HTS), and the application of a new generation of high-resolution orbital mass analysers [20]. This has led to techniques such as affinity purification mass spectrometry and genetic screening, becoming more common for receptor identification. In this review, we will compare and contrast different genomic and interactome approaches utilised for the identification of host protein receptors.

\section{Genomic approaches}

Genomic approaches have undergone significant advances over the past 2 decades, in particular through the evolution of HTS techniques. Genomic approaches can be divided into two categories: loss of function (LOF) or gain of function (GOF). LOF approaches inactivate host factors, allowing their influence on viral infections to be observed. In theory, genome-wide screening with this approach allows for the identification of all host factors, which either promote or inhibit infection. In contrast, GOF approaches introduce single new functionalities, from permissive cell lines into non-permissive ones. Virus entry can then occur if the GOF results in the expression of a functional receptor. In this review, we compare four gene perturbation techniques: complimentary DNA (cDNA), RNA interference (RNAi), random insertional mutagenesis, Clustered Regularly Interspaced Short Palindromic Repeats/CRISPR associated protein 9 (CRISPR/Cas9) knockouts, activation (CRISPRa), and interference (CRISPRi). Currently, CRISPRa and CRISPRi have not been reported to our knowledge in any receptor identification reports, although CRISPRa has been used to identify viral host factors [21]. We consider that these two approaches, which have fewer off-target effects, will most likely be very useful in the future, but as such fall out of the scope of this review [22, 23]. CRISPR/Cas9 knockouts are discussed in the "Genetic Knockouts section".

\section{Genetic knockdowns}

Genetic knockdowns can be produced using RNA interference (RNAi) or CRISPR interference (CRISPRi). RNAi is a common approach utilised in LOF genetic screens and has been extensively reviewed [24-29]. RNAi acts to silence genes through the temporary removal of cellular mRNA, by RNA-induced silencing complexes (RISC) (Fig. 1) (reviewed in [30]). The RISC mechanism is universal, allowing RNAi to be used in many cell lines.

There are three tools used to achieve RNAi: small interfering RNAs (siRNAs), short hairpin RNAs (shRNAs), and long double-stranded RNAs (dsRNAs). However, the use of dsRNA is limited, as its presence induces the interferon response within vertebrate systems [31]. This causes cellular protein synthesis to close down, preventing specific loss of function phenotypes from being observed. Nevertheless, dsRNAs remain a good option for work within insect cell lines (reviewed in [32]). In 2011, a genome-wide dsRNAi screen within Drosophila cells identified nine transmembrane genes required for Sindbis virus infection [33]. Drosophila natural resistance-associated macrophage protein (dNRAMP), the homologue of mammalian NRAMPs, was the only ubiquitously expressed, plasma membrane-associated protein identified. Molecular and biochemical assays demonstrated that dNRAMP yields a fivefold improvement in virus attachment and is not required in processes downstream of entry, verifying its role as a virus receptor. Furthermore, mice deficient in NRAMP2 demonstrated a 50-fold decrease in Sindbis virus infectivity, highlighting the potential of performing dsRNAi screens in Drosophila cells, to identify potential mammalian virus receptors.

In contrast to dsRNAs, both shRNAs and siRNAs can be used in mammalian systems. siRNAs are directly transfected into cells and can be used in transient 3-7 day screens. Ephrin receptor A2 (EPhA2) was identified as an epithelial cell receptor for Epstein-Barr virus (EBV) using targeted siRNA screening [34]. Previously, it was reported that epidermal growth factor increases EBV infectivity [35]. Pretreating cells with epidermal growth factor and monitoring the transcription level in a microarray screen identified six upregulated genes. The initial hits were then probed using siRNAi and only EPhA2 knockdown was shown to 


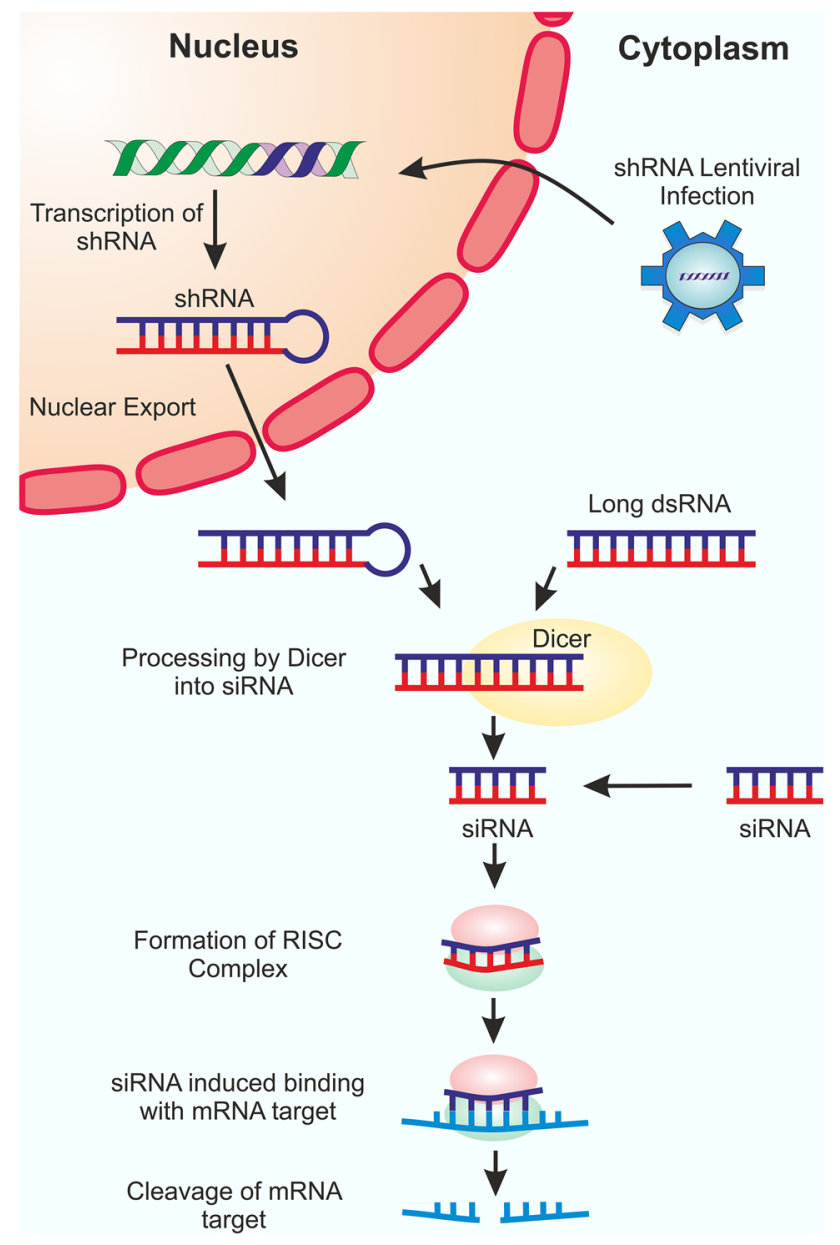

Fig. 1 Schematic representation of RNAi silencing mechanism. For shRNA LOF screening, a lentiviral vector or plasmid encoding the shRNA (blue) is first integrated into the cellular DNA (green). The DNA is then transcribed by RNA polymerase III into shRNA and the shRNA exported into the cytoplasm by Exportin 5. For dsRNA and siRNA LOF screening, the interfering RNA is directly transfected into the cells. Both shRNAs and dsRNAs are processed in the cytoplasm by Dicer into siRNAs. The siRNAs are then loaded into the RISC and the passenger strand removed from the guide strand. The guide strand can then direct the RISC to the complementary mRNA target, where RISC cleaves the mRNA, leading to its degradation

significantly decrease infectivity. The results were confirmed with three distinct siRNAs, thus excluding off-target effects. The results were then further validated using ectopic expression of complementary DNA, CRISPR/Cas9 knockdown, and co-immunoprecipitation assays. Finally, EPhA2 was determined to act as a receptor by monitoring the rate of virus internalisation in WT, EPhA2 knockdown, and EPhA2 knockout cell lines.

shRNAs are delivered to the nucleus in a plasmid or lentivirus, and integrated into the host's DNA, where they are then transcribed leading to the slow accumulation of shRNAs in the cytoplasm. Unlike siRNAs, shRNA expression is stable allowing for long-term screening ( $>10$ days).
However, expression of shRNAs may be lost if the cells lose the plasmid, or if the lentivirus integration is silenced due to negative epigenetic regulation $[36,37]$. Therefore, cells need to be cultured under selection for the shRNA phenotype. shRNAi has mainly been used to validate hits identified through other methods. shRNAi was performed on Bombyx mori embryonic cells to knockdown the cholesterol transporter Niemann-Pick C1 (NPC1) [38]. NPC1 was proposed as a potential baculovirus receptor, due to its interaction with Bombyx mori promoting protein which increases baculovirus production. Two unique shRNAs were used to target the NCP1 gene and a $40 \%$ reduction in NCP1 expression was achieved, leading to a substantial reduction in baculovirus infectivity. The receptor was then further validated by performing co-immunoprecipitation experiments with NCP1 and the major baculovirus glycoprotein, gp64. NCP1 was also identified as a potential receptor for Ebola virus, by genetic knockout screening in haploid cells [39]. This was validated by shRNA knockdown of NPC1 in human peripheral blood monocytederived dendritic cells, which yielded them resistant to filovirus infection.

A major issue with RNAi is a lack of reproducibility between similar studies [40-42] despite efforts to minimise false positives [43, 44]. This has been investigated by directly testing the degree of overlap between two identical genomic screens. Hit lists containing 513 and 1140 hits were observed for two replicate screens, highlighting the impact of off-target effects, caused by both false-positive and false-negative results [45]. False positives occur due to the partial complementarity of siRNAs to multiple mRNAs throughout the 'seed' region (nucleotides 2-8 of the 21 present in the siRNA sequence). When binding occurs through the seed region, this leads to translational repression and degradation of the mRNA, via the microRNA pathway leading to off-target effects [46]. False negatives can be generated by cytotoxic knockouts leading to cell apoptosis [47], functional redundancies caused by gene duplication preventing phenotypic manipulation by single gene knockdowns [48], variation in experimental conditions [49], and systematic errors [50].

Despite these limitations, RNAi is easy to use, has a fast knockdown of 24-48 h, and uses stable reagents, making it a good choice for generating loss of function phenotypes. Furthermore, as RNAi has a knockdown efficiency which is lower than $100 \%$, this allows the study of essential genes, as the cells can survive, whilst the virus infection may be measurably inhibited. This is a major advantage over other loss of function gene perturbation methods, such as CRISPR/Cas9 or random insertional mutagenesis genetic knockouts, where permanent null phenotypes are generated. 


\section{Genetic knockouts}

Achieving complete genetic knockdowns using RNAi is difficult. To create true genetic knockouts, which demonstrate a permanent homozygous null phenotype, deleterious gene mutations must be generated. True genetic knockouts can be generated using either random or sitespecific mutagenesis.

In random mutagenesis (reviewed in [51]), cells are, for example, transduced with a retroviral genetrap vector, containing a strong adenoviral splice acceptor site and a marker gene, such as green fluorescent protein. Following transduction, genetrap vectors are integrated into introns, leading to the production of truncated mRNAs [52]. The disrupted genes can then be identified, using the integrated DNA sequences as a molecular tag. Transduction with genetrap vectors leads to biased insertion near active promoters, ensuring the generation of complete knockouts [53]. The two main drawbacks are that it generates non-universal dispersed insertions, which may prevent all loci being targeted [54], and it is inefficient in diploid cell lines, where deleterious mutations must be generated in both chromosomes. This latter issue can be overcome through the use of haploid cell lines [55]. Screening using genetrap insertional mutagenesis, within haploid human cells (HAP1), identified receptors for both Ebola and adeno-associated virus serotype 2 (AAV2), [39, 56]. In 2011, NCP1 was identified as a receptor for Ebola virus, accounting for 39 hits out of $\sim 800,000$ insertions. NCP1 was validated as a virus receptor by virus binding, replication and internalisation assays, and shRNA knockdown. In 2016, a library of mutagenized HAP1 cells containing almost all non-lethal knockouts was infected with AAV2 that expresses red fluorescent protein. Fortysix significant hits were identified from cells resistant to infection. Of these hits, a previously uncharacterized type I transmembrane protein, KIAA0319L, showed the greatest enrichment and was associated with 57 independent mutations. KIAA0319L was then confirmed as a receptor by generating CRISPR/Cas9 knockouts in eight different cell lines. All cell lines showed resistance to infection that was rescued through ectopic expression of KIAA0319L.

Site-specific mutagenesis can be performed using the CRISPR/Cas9 technology, which has the advantage that it equally targets all loci [57]. Although Cas9 is the most studied CRISPR associated protein, multiple CRISPR/ Cas subtypes exist within prokaryotic organisms [58]. The CRISPR/Cas9 system evolved as an adaptive immune system within bacteria and archaea, employing a transacting CRISPR RNA: CRISPR RNA (tracrRNA:crRNA) duplex to target and destroy pathogenic DNA [59]. When performing genomic experiments, a fusion of the
tracrRNA:crRNA duplex, known as a single-guide RNA (sgRNA) may be used. CRISPR/Cas9 knockouts are achieved through the generation of sgRNA targeted double-stranded DNA breaks, which, following error-prone non-homologous end joining, lead to the generation of null phenotypes (Fig. 2: CRISPR/Cas9 Knockout) [60, 61]. In 2019 , receptors for both encephalomyocarditis virus and human cytomegalovirus (HMCV) were identified using genome-wide CRISPR/Cas9 screens with the GeCKOv2 sgRNA library. The library targets 19,050 genes with six sgRNAs per gene [62-64]. To identify receptors specifically required for HMCV infection in epithelial cells, Xiaofei et al. performed parallel CRISPR/Cas9 screens in ARPE-19 epithelial cells and HEL fibroblasts [63]. The multipass membrane protein, OR14I1, was identified as an initial hit exclusive to the epithelial cell screen, and validated as a viral receptor by shRNA knockdown followed by ectopic expression rescue, neutralisation, virus blocking and virus entry assays. Two identical CRISPR/ Cas9 screens within HeLa cells identified nine initial hits associated with encephalomyocarditis virus infection in replicate pools. A disintegrin and metalloproteinase nine domain (ADAM9) was the most significant hit with all six sgRNAs being significantly enriched. ADAM9 knockouts were also shown to be resistant to virus infection in both primary lung fibroblasts (pLF) from mice and HEK293T cells. ADAM9 was confirmed to function as an entry receptor through the use of RNA bypass assays. In addition, ADAM9 was independently identified as a receptor for encephalomyocarditis virus, using genetrap mutagenesis screening in haploid cells [65]. This shows that genetic knockout screening is a robust technique for receptor identification (Table 1).

In contrast to RNAi, CRISPR/Cas9 knockouts have been shown to produce fewer false negative results [84]. Additionally, CRISPR/Cas9 knockout screens have been developed within haploid cell lines, therefore increasing the reliability of generating gene disrupted phenotypes [85]. Due to tolerated mismatches at the sgRNA-target site interface, false positives also occur using CRISPR/Cas9 but at a $34 \%$ lower rate than with RNAi [86-88]. False positives can be reduced through the use of truncated sgRNAs (17-18 nucleotides compared to 20 nucleotides), which have a lower DNA-binding affinity and, therefore, are unable to tolerate mismatches in the target DNA [89]. Additionally, mutant CRISPR/Cas9 systems which require the correct localisation of two CRISPR/Cas9 monomers to induce gene knockouts can also limit off-target effects. This approach is exemplified by CRISPR/Cas9 nickases, where the Cas 9 molecule has been mutated to only introduce single-stranded DNA breaks, and therefore, two closely spaced CRISPR/Cas9 complexes are required to introduce staggered double-stranded DNA breaks (Fig. 2: CRISPR/Cas9 Nickase Knockout) [90]. As single-stranded nicks are repaired with 


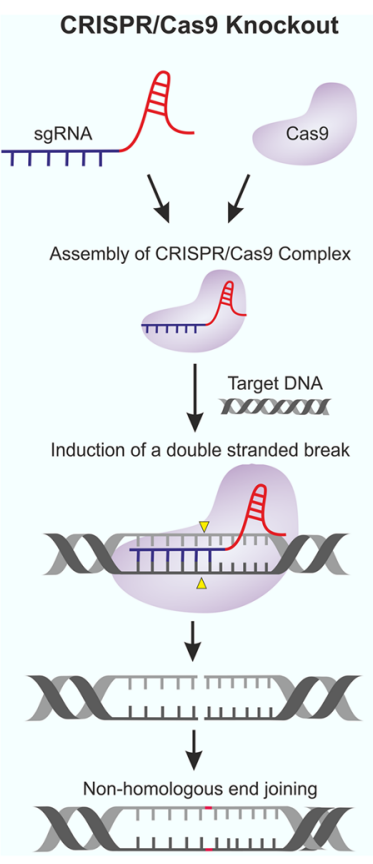

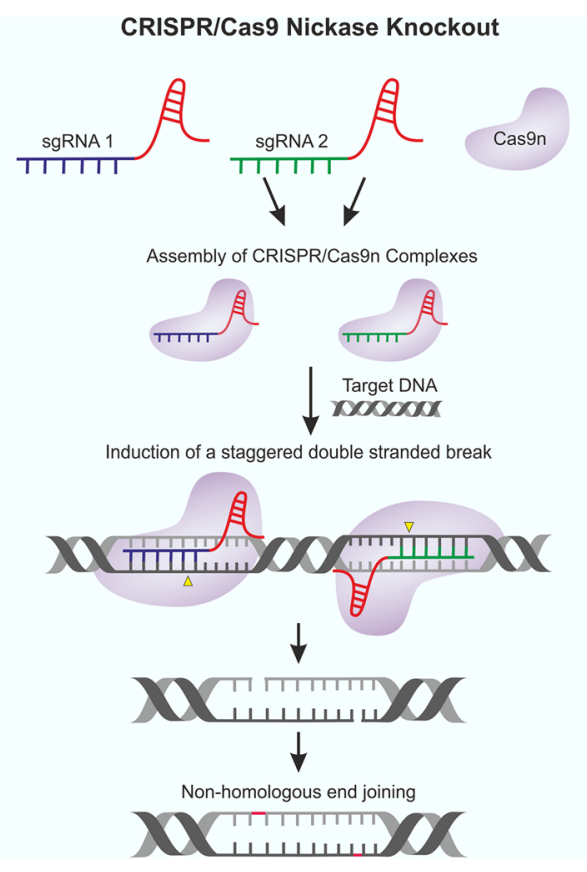
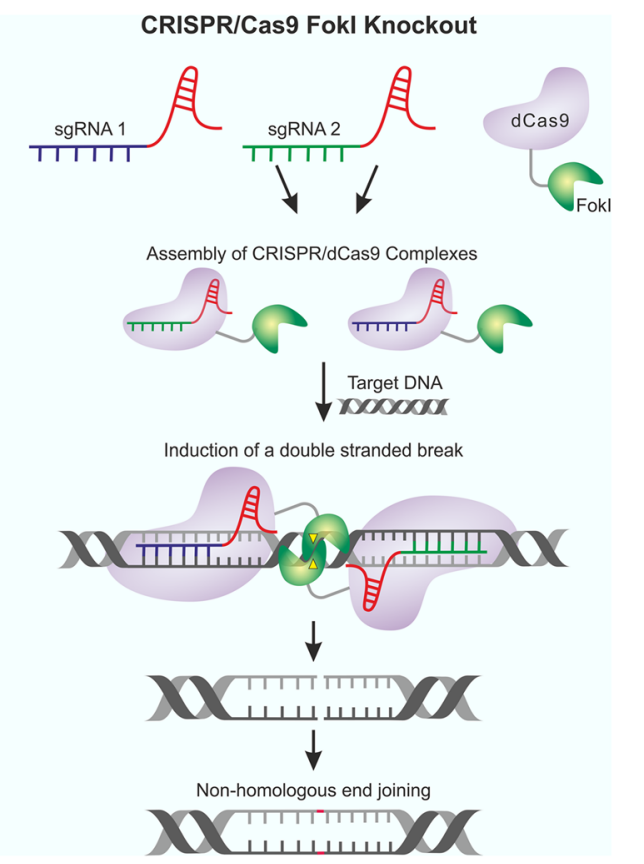

Fig. 2 Schematic representation of CRISPR/Cas9, CRISPR/Cas9 nickase, and CRISPR/Cas9 FOKI genetic knockout mechanism. CRISPR/Cas9 genetic knockout: the CRISPR/Cas9 complex is first formed by combining an sgRNA and a Cas9 endonuclease. The sgRNA then guides the CRISPR/Cas9 complex to a specific region of the genomic DNA, and a double-stranded DNA break is induced by the Cas9 endonuclease. The double-stranded DNA break is then repaired non-homologously by the host cell, leading to the formation of insertions or deletions, which disrupt the open reading frame of the gene. CRISPR/Cas9 nickase genetic knockout: two CRISPR/ Cas9 nickase complexes are formed with two separated sgRNAs and mutated Cas9 nickase endonucleases. The sgRNAs then guide the CRISPR/Cas9 complexes to specific regions of the genomic DNA, and two single-stranded DNA breaks are induced by the Cas 9 endonucleases, forming a staggered double-stranded break. The doublestranded DNA break is then repaired non-homologously by the host cell. CRISPR/Cas9 FOKI genetic knockout: Two CRISPR/Cas9 FOKI complexes are formed with two separated sgRNAs and mutated dead Cas9 fused with the endonuclease FOKI. The sgRNAs then guide the CRISPR/Cas9 complexes to specific regions of the genomic DNA and the FOKI units dimerise. The FOKI dimer then induces a double-stranded DNA break which is repaired non-homologously high fidelity by base excision repair, this minimises the generation of off-target gene depletions [91]. In another approach, the Cas9 nuclease activity has been removed and the endonuclease domain of FokI fused to the Cas9. This mutant CRISPR/ Cas9 system can only induce double-stranded DNA breaks when two FokI endonuclease domains undergo dimerization, as FokI is not active in its monomeric form (Fig. 2: CRISPR/ Cas9 FokI Knockout) [92]. Although the utilisation of nickases or Cas9 FOKI can reduce off-target effects, they also possess challenges for delivery with viral vectors, due to their increased nucleic-acid payload size. Therefore, the development of higher fidelity variants of Cas9 through protein engineering is favourable. Several such high fidelity Cas9s have now been developed including: SpCas9-HF1 [93], SniperCas9 [94], and eSpCas9 [95].

\section{Ectopic expression of complementary DNA}

In contrast to RNAi, random insertional mutagenesis, and CRISPR/Cas9 knockouts, cDNA libraries are used to introduce new functionalities into cell lines. cDNA libraries are synthesised from mRNA using reverse transcriptases, before being cloned into plasmid or lentiviral expression systems [96-98]. These libraries can then be utilised in GOF screening, whereby cDNA libraries developed from susceptible cell lines are transduced into non-susceptible cell lines, and retested for susceptibility. cDNA libraries have been used for receptor identification since the 1990s [9, 75, 76]. In 2018, a cDNA library containing $8.4 \times 10^{6}$ primary clones derived from ARPE-19 
Table 1 Examples of identified cellular receptors with the identification method used

\begin{tabular}{|c|c|c|c|}
\hline Virus & Identified receptor & Identification method & References \\
\hline Sindbis virus & NRAMP & RNAi screening & {$[33]$} \\
\hline Epstein-Barr virus & Ephrin receptor A2 & RNAi screening & [34] \\
\hline Ebolavirus & Niemann-Pick C1 & $\begin{array}{l}\text { Random insertional mutagenesis in Haploid } \\
\text { cells }\end{array}$ & [39] \\
\hline Adeno-associated virus (AAV) serotype 2 & KIAA0319L & $\begin{array}{l}\text { Random insertional mutagenesis in Haploid } \\
\text { cells }\end{array}$ & {$[56]$} \\
\hline Lassa virus & LAMP1 & $\begin{array}{l}\text { Random insertional mutagenesis in Haploid } \\
\text { cells }\end{array}$ & {$[66]$} \\
\hline Human-type A enteroviruses & kremen 1 & $\begin{array}{l}\text { Random insertional mutagenesis in Haploid } \\
\text { cells }\end{array}$ & {$[67]$} \\
\hline NRP2 & Lujo virus & $\begin{array}{l}\text { Random insertional mutagenesis in Haploid } \\
\text { cells }\end{array}$ & {$[68]$} \\
\hline Encephalomyocarditis virus & ADAM9 & CRISPR/Cas9 screening & {$[64]$} \\
\hline Human cytomegalovirus & OR14I1 & CRISPR/Cas9 screening & {$[63]$} \\
\hline Norovirus & CD300If & CRISPR/Cas9 screening & {$[69,70]$} \\
\hline Arthritogenic alphaviruses & Mxra8 & CRISPR/Cas9 screening & [71] \\
\hline Andes virus and Sin Nombre virus & Protocadherin & CRISPR/Cas9 screening & [72] \\
\hline Enterovirus B & Neonatal Fc receptor & CRISPR/Cas9 screening & {$[73]$} \\
\hline Bat influenza virus & Human leukocyte antigen DR isotype & CRISPR/Cas9 screening & [74] \\
\hline Hepatitis $C$ virus & Claudin-1 and occludin & cDNA libraries & {$[8,10]$} \\
\hline Bombyx mori nucleopolyhedrovirus & SINAL10 & cDNA libraries & [75] \\
\hline Human cytomegalovirus & CD147 & cDNA libraries & [76] \\
\hline Japanese encephalitis virus & Hsp70 & VOPBA & [77] \\
\hline Old World arenaviruses & $\alpha$-Dystroglycan & VOPBA & {$[78]$} \\
\hline Human cytomegalovirus & Nrp2 and PDGFRa & Protein microarrays & [79] \\
\hline New world arenaviruses & Transferrin receptor & Affinity capture mass spectrometry & {$[80]$} \\
\hline Nipah virus & Ephrin B2 & Affinity capture mass spectrometry & {$[81]$} \\
\hline Japanese encephalitis virus & PLVAP and GKN3 & Affinity purification-mass spectrometry & {$[82]$} \\
\hline Vaccinina virus & AXL, M6PR, DAG1, CSPG4 and CDH13 & Cross-linked mass spectrometry & {$[83]$} \\
\hline
\end{tabular}

epithelial cells was used to identify genes that promote HMCV entry [76]. HeLa cells which have a low HCMV infection rate of $1-5 \%$ were transfected with the cDNA library and infected with HMCV that expresses green fluorescent protein (GFP). Approximately 100 out of 1 million clones showed an increase in green fluorescence, indicative of increased infectivity. DNA sequencing of the GFP expressing clones identified the cell surface molecule CD147 as a potential receptor. This was confirmed by shRNA knockdown, HMCV entry assays and co-localisation immunofluorescence. GOF and LOF approaches are strongly complimentary, with cDNA rescue experiments acting as a major verification method for hits identified in RNAi screening (reviewed in [99]).

There are, however, several drawbacks to consider when using cDNA libraries for GOF screening. Firstly, it may be difficult to obtain a suitable non-susceptible cell line. Second, non-susceptible cell lines must be genetically manipulable. Third, the number of copies of each gene within the cDNA library is potentially biased by the abundance of
mRNA in the susceptible cell line at the time of isolation. Therefore, receptors which have low expression levels may not be represented in cDNA libraries, preventing their identification. Fourth, cDNA libraries may contain truncated cDNA clones arising from early termination of reverse transcriptase activity. The inclusion of truncated cDNAs in the library can be prevented using high efficiency cloning methods which isolate full-length cDNAs using two dimensional electrophoretic separation [100]. Finally, the reverse transcriptase step is error prone, and therefore, unwanted mutations within the cDNA library may lead to false negatives [101].

\section{Interactomics and proteomics}

In contrast to the previously described genomic approaches, interactome and proteomics aim to directly identify the protein-protein interactions (PPIs), which occur between virus attachment proteins and their host receptors. Historically, 
this has been performed using virus overlay protein binding assays (VOPBA) (reviewed in [102]). Although VOPBA have successfully identified receptors for several viruses, including lymphocytic choriomeningitis virus and lassa virus [78], VOPBA suffer from several problems. In VOPBA, all cellular proteins are subjected to gel electrophoresis, transferred onto a membrane, and then probed with virus. Bands where virus-receptor interactions occur can then be visualised with antibodies, and the corresponding protein in a duplicate gel identified using mass spectrometry. Failure to identify receptors can occur if the necessary three-dimensional conformation of the attachment domains or receptor complexes is destroyed by SDS-PAGE. Furthermore, it may not be possible to detect virus-receptor interactions which have low binding affinities [103]. More recent methods remove the need for gel electrophoresis, instead probing virus-receptor interactions in more native environments, overcoming some of the issues present by VOPBA. Here, we will discuss the use of protein microarrays, affinity purification-mass spectrometry (AP-MS), and cross-linked mass spectrometry (XL-MS) for receptor identification.

\section{Protein microarrays}

Unlike VOPBA protein microarrays allow for the direct detection of PPIs without the requirement of SDS-PAGE. First, a protein microarray is generated by immobilising purified 'bait' proteins onto a glass slide. Next, the microarray is probed with virus, and the PPIs detected through the use of fluorescently-, enzymatically-, or radio-labelled recombinant proteins within the array, surface plasmon resonance imaging, atomic force microscopy, electrochemical impedance spectroscopy, and mass spectrometry (reviewed in [104])

The first functional protein array was developed by Zhu et al. in 2001 and used to determine substrate specificity within the yeast proteome [105]. Since then, many protein microarrays have been developed, including several commercial microarrays (reviewed in [106]). Nevertheless, protein microarrays which target extracellular receptors remain few and far between. This can be partially attributed to the difficulties associated with the production of soluble transmembrane proteins. In 2007, Bushell et al. developed an avidity-based extracellular interaction screen (Avexis), where they recombinantly expressed the extracellular domains of transmembrane proteins, removing the insoluble transmembrane region [107]. To identify low-affinity interactions, the proteins were additionally tagged with a coiled-coil sequence from the rat cartilage oligomeric matrix protein. This causes the pentamerization of the 'bait' proteins and increases binding avidity.
In 2018, a high-throughput screening approach, based on Avexis was utilised for the identification of HMCV-receptor interactions [79]. A library containing the ectodomains of 1297 human single transmembrane receptors was set up on an automated, cell independent platform. The library was then probed with the HMCV envelope glycoprotein pentamer, gHgLpUL128-131A, and trimer, gHgLgO. Three hits were identified for the trimer: platelet-derived growth factor receptor A (PDGFRa), transforming growth factor beta receptor type 3 (TGFbRIII), and neuregulin2 (NRG2), and four hits for the pentamer: neuropilin-2 (Nrp2), thrombomodulin (THBD), the leukocyte immunoglobulin-like receptor (LILRB3), and the immunoglobulin alpha Fc receptor (FCAR). The interactions were then probed using biolayer interferometry and surface plasmon resonance. No interaction could be detected for NRG2 or FCAR, and only weak binding to LILRB3; therefore, these hits were excluded from further studies. The remaining potential receptors were then validated using competition assays with both recombinant protein and anti-receptor antibodies, lentiviral overexpression, and CRISPR/Cas9 knockdown. It was determined that only Nrp2 and PDGFRa acted as functional receptors in vivo. Although THBD and TGFbRIII interact with HMCV in vitro, they were not shown to be essential for virus entry.

Although protein microarrays have the ability to detect PPIs in vitro, the detected interactions may not be biologically relevant in vivo. This is mainly due to difficulties associated with producing recombinant proteins, which possess native post-translational modifications, such as glycans or disulphide bonds. Another limitation of protein microarrays is the cost and time requirements associated with generating large-scale libraries of recombinant proteins. A method to overcome this is the use of nucleic-acid programmable protein arrays (NAPPA), where DNA is directly deposited onto the microarray and the proteins are synthesised in situ using in vitro transcription and translation (IVTT) [108]. In 2016, a proof-of-concept study utilised IVTT and microfluidics to create an array of $\sim 2100$ proteins from $\sim 2700$ linear synthetic genes [109]. The array was then probed with simian virus 40 (SV40) and 99 interactions were observed, including 14 of the 22 positive controls. This demonstrates a high false-negative discovery rate of $36 \%$. Finally, 25 hits were subjected to validation by co-immunoprecipitation, which confirmed 18 hits.

\section{Affinity purification-mass spectrometry}

AP-MS is one of the most common proteomic approaches used for the identification of virus-host interactions. The AP-MS, workflow is as follows: first, the host cells are infected with virus, allowing for the formation of 


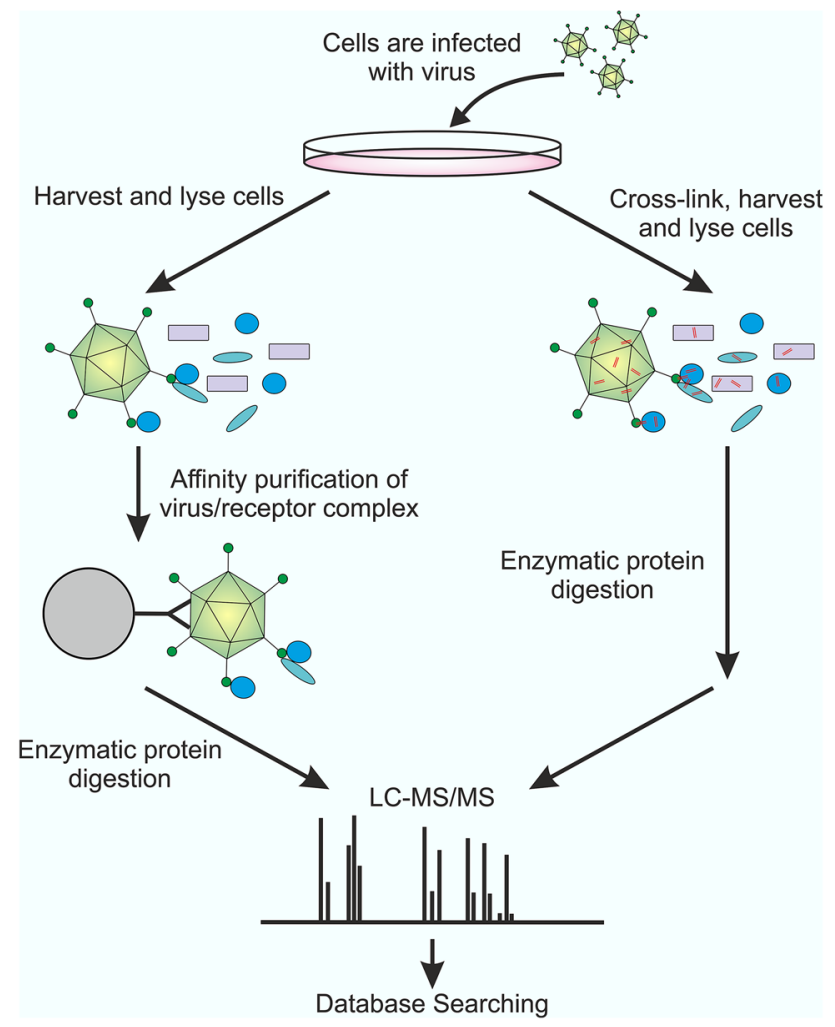

Fig. 3 AP-MS and XL-MS workflow comparison. AP-MS workflow: cells are first infected with the virus of interest, harvested, and lysed. The virus-receptor complexes are then isolated using affinity purification, and the purified proteins enzymatically digested and identified using LC-MS/MS and database searching. In XL-MS, the cells are also first infected with virus. However, a chemical crosslinking reaction is then performed, before the harvesting and lysis of the host cells. Next, the proteins are enzymatically digested and identified using LC-MS/MS and database searching

virus-receptor complexes. Following cell lysis, the complexes are then isolated by affinity purification. Finally, the complexes can be identified and quantified using mass spectrometry (Fig. 3).

Often affinity capture with antibodies has been used to isolate virus-receptor complexes prior to analysis by mass spectrometry [110]. This requires a high affinity, specific antibody, preferentially recognising a conformational epitope of the virus capsid that is not hidden by receptor binding. Alternatively, affinity-tagged viruses can be used $[111,112]$. This method enables binding partners against the affinity tag to be used in the affinity purification step. Therefore, tags can be chosen for which high affinity binding partners are readily available. To produce affinity-tagged virus, the virus either needs to be genetically tractable (e.g., through reverse genetics) to introduce the tag, or the affinitytagged protein is incorporated through in trans expression of the gene during virus infection. Again, the tag insertion should not sterically hinder receptor binding. Although not used to identify viral receptors, this approach has been used to identify virus-host interactions, involved in replication within dengue virus serotype 2 (DENV-2) [113]. Here, the full-length DENV-2 RNA genome containing a polyhistidine and FLAG-tagged NS5 was synthesised in vitro using T7 RNA polymerase. Huh-7 cells were then infected with tagged-DENV-2, and the NS5 complexes isolated via FLAG pull-down $48 \mathrm{~h}$ post-infection, leading to the identification of 97 interacting proteins. The most common AP-MS approach used in the identification of viral receptors is the use of individually tagged recombinant viral glycoproteins. The approach was used recently in 2018 to identify host cell receptors for Japanese encephalitis virus (JEV) [82]. Affinity purification was performed using plasma membrane fractions of $\mathrm{BALB} / \mathrm{c}$ mouse brain and the recombinant expressed, his-tagged, envelope protein of JEV, identifying 42 interacting proteins. Hits were then analysed for mRNA upregulation during JEV infection and the envelope-host protein interactions studied in silico. Two hits, plasmalemma vesicle-associated protein and gastrokine three were then validated as viral receptors by overexpression using cDNA and knockdown using siRNAi. Although frequently used, this approach may not faithfully reproduce receptor-binding sites due to the exposure of surfaces that are hidden within virus assembly, therefore leading to the identification of false positives.

False positives can also occur during AP-MS experiments due to the co-isolation of non-specifically bound proteins. The presence of non-specifically bound proteins can partially be reduced through the use of tandem affinity purifications [114]; where two different epitope tags are incorporated into the recombinant virus, and the virus-receptor complexes are purified in two consecutive affinity purification steps.

\section{Cross-linking mass spectrometry}

The interactions between viral attachment proteins and host receptors are intermolecular and transient; therefore, their direct detection within native environments is challenging. Cross-linking can overcome this, by introducing covalent linkages between the viral attachment protein and the host receptor. In the early 1970s, cross-linking was used in conjunction with gel electrophoresis, to identify PPIs within ribosomes [115]. More recently, cross-linking has been combined with high-resolution mass spectrometry (XL-MS), to identify PPIs and their physical interaction contacts [83].

During XL-MS, interacting proteins are covalently tethered using chemical cross-linkers. Following cross-linking, the proteins are enzymatically digested, resulting in a complex peptide mixture. This peptide mixture is then analysed using liquid chromatography-tandem mass spectrometry 
(LC-MS/MS) and the cross-linked peptides identified by comparing experimental MS/MS spectra, against a database of computationally generated theoretical spectra. As the length of the cross-linkers is known, these can be used as distance constraints in order to perform structural modelling [reviewed in [116]].

There are numerous different types of cross-linkers available including: homobifunctional cross-linkers, heterobifunctional cross-linkers, zero-length cross-linkers, and trifunctional cross-linkers [reviewed in [117] ]. Trifunctional cross-linkers are particularly useful, as they allow for the introduction of additional functionalities, such as biotin handles, which can be used for affinity purification of the cross-linked species following protein digestion [83, 118]. Furthermore, trifunctional cross-linkers can also incorporate chemical cleavage sites to remove the biotin moiety following purification and an isotopically labelled spacer arm, which can be used for quantitation [119]. Frei et al. [120] performed a proof-of-concept study, whereby they identified seven cell surface proteins as potential virus receptors for mature vaccinia viruses, using a novel trifunctional chemoproteomic reagent (TRICEPS) in XL-MS. The TRICEPS reagent contains three functionalities: an NHS ester for coupling to ligands via primary amines; a trifluoroacetylprotected hydrazine that can bind glycoproteins on the cell surface following the introduction of aldehydes via mild oxidation, and a biotin group for affinity purification of the cross-linked products. To validate the hits, the proteins were subjected to siRNA knockdown and five proteins AXL, M6PR, DAG1, CSPG4, and CDH13 were shown to reduce virus infectivity by $40-60 \%$. Furthermore, three of the proteins identified: CSPG4, DAG1, and AXL had previously been identified as virus receptors or attachment factors using competition assays, mutagenesis studies, and co-localisation experiments [121-123]. Despite the success of this proof-ofconcept study, no further virus receptors have been identified using XL-MS. A possible cause for this is the complexity of data analysis associated with XL-MS (reviewed in [124]).
MS/MS fragmentation is complicated for cross-linked peptides, as the resulting peptide contains fragments from two proteins. This leads to a higher precursor charge state and a greater number of fragment ions. Furthermore, four types of cross-linked peptides can be present in the sample: dead-end cross-links, intrapeptide cross-links, interpeptide cross-links, and higher order cross-linked peptides. Consequently, to identify peptides, all possible peptide-peptide combinations need to be considered when performing database searches, drastically increasing the search space. Several specialised algorithms and software packages have been developed, which can aid in the identification of peptides (reviewed in [124]). We expect that such algorithm adaption will lead to more discoveries in the near future.

\section{Practical considerations}

\section{Genetic screening approach}

There are two types of screening approaches which can be adopted: pooled and arrayed, with each method possessing a unique set of advantages (Table 2). In pooled screening, a population of cells is either transduced with an RNA or cDNA library (RNAi, CRISPR/Cas9, and cDNA), or subjected to retroviral gene trapping (haploid cell knockouts). The pooled cells then undergo selection for transduction or retroviral incorporation, and the populations are expanded. Following expansion, the cells are infected with the virus in question, and enrichment is performed either looking for a GOF or LOF that has an effect. Finally, hits are identified by next-generation sequencing [125-127].

In arrayed RNAi, CRISPR/Cas9, and cDNA screening, cells are also transduced with an RNA or cDNA library [128]. However, in contrast to pooled screening, a single gene is targeted in each well, of a multi-well plate. In arrayed, random insertional mutagenesis screening, knockouts are first generated within low cell density pools; the

Table 2 Advantages and disadvantages of pooled and arrayed genomic screening approaches

\begin{tabular}{|c|c|c|}
\hline & Pros & Cons \\
\hline Arrayed screening & $\begin{array}{l}\text { Can select a gradation of phenotypes } \\
\text { Rapid identification using library key } \\
\text { Short-term screening (less than } 10 \text { days) } \\
\text { Can be used for high-throughput screening } \\
\text { Custom-made libraries are available }\end{array}$ & $\begin{array}{l}\text { For haploid cells, this requires long-term culturing and } \\
\text { storage of numerous cell lines } \\
\text { Attached cells only } \\
\text { Expensive to purchase, use, and maintain libraries } \\
\text { Requires high-throughput plate reader or microscope for } \\
\text { analysis }\end{array}$ \\
\hline Pooled screening & $\begin{array}{l}\text { Simple setup } \\
\text { Does not require any specialised equipment } \\
\text { Can be used with suspension cells } \\
\text { Long-term screening (greater than } 10 \text { days) } \\
\text { Lower cost, particularly when performing survival } \\
\text { screens }\end{array}$ & $\begin{array}{l}\text { PCR/next-generation sequencing needed to identify hits } \\
\text { Cannot perform high-throughput screening } \\
\text { Requires high cell number } \\
\text { Requires a selection step } \\
\text { Limited number of readouts }\end{array}$ \\
\hline
\end{tabular}


individual colonies are then picked and cultured in multiwell plates [129]. Following knockdown or ectopic expression, the cells are infected with the virus in question, and the viral replication or cell number monitored for a GOF or LOF effect. Finally, hits are identified using the library key.

\section{Choice of cell line, tissue, or animal model}

Viruses demonstrate varying host ranges and tissue tropisms. Whether or not a cell is susceptible to infection is dependent on the expression of suitable entry receptors on the cell's surface. However, some viruses may utilise different receptors depending on the cell type, allowing them to be more promiscuous. Therefore, receptors identified within a specific haploid or diploid cell line, are not necessarily representative of all the receptors used by the virus, within all hosts, or all host tissues. This has been demonstrated for adenovirus serotype 5, where the coxsackievirus and adenovirus receptor (CAR) has been shown to act as the primary receptor in vitro. However, the vitamin K-dependent coagulation factor X (FX) acts as an alternative receptor within the human liver, bypassing CAR, and initiating infection [130, 131]. Furthermore, some viruses have been shown to adapt to cell culture conditions allowing them to utilise new receptors such as heparin sulphate [132]. The use of 3D cell models and animal models may lead to the identification of different receptors to those found in standard cell culture [133].

\section{Conclusions}

The study of virus-receptor interactions is crucial for the development of antiviral drugs, vaccines, and new diagnostic technologies. Nevertheless, receptor identification has often been a laborious and time-consuming process. Highthroughput approaches now provide alternative, potentially faster methods for host receptor discovery, and have been used to identify numerous receptors within recent years (Table 1). In particular, genetic knockout screening has grown in popularity, leading to the discovery of several bona fide new receptors since 2017, including: NRP2 for Lujo Virus, protocadherin for Andes virus and Sin Nombre virus, kremen 1 for multiple human-type A enteroviruses, neonatal $\mathrm{Fc}$ receptor for enterovirus $\mathrm{B}$, and human leukocyte antigen DR isotype for bat influenza viruses [67, 68, 72-74].

Despite numerous elegant studies, our knowledge of entry receptors still remains limited. This can be linked to a series of experimental challenges including: the use of relevant cell lines, tissues or animal models; the production of suitable virus strains, genetic tractability, and the identification of interactions in native environments (Tables 2,3). Many of these methods result in multiple candidate molecules being identified and

Table 3 Advantages and disadvantages of proteomic approaches

\begin{tabular}{|c|c|c|}
\hline & Pros & Cons \\
\hline Protein microarrays & $\begin{array}{l}\text { Several microarrays available commercially } \\
\text { Low avidity binding detected using 'bait' protein } \\
\text { pentamerization } \\
\text { Quick generation of large-scale libraries using } \\
\text { nucleic-acid programmable protein arrays } \\
\text { Several methods used to detect interactions }\end{array}$ & $\begin{array}{l}\text { Detected interaction may not be biologically } \\
\text { relevant in vivo } \\
\text { Difficult to produce recombinant proteins, with } \\
\text { native post-translational modifications } \\
\text { Time-consuming and expensive to generate librar- } \\
\text { ies of recombinant proteins } \\
\text { High false-negative discovery rate in nucleic-acid } \\
\text { programmable protein arrays }\end{array}$ \\
\hline Affinity purification-mass spectrometry & $\begin{array}{l}\text { Affinity tagging allows the study of proteins } \\
\text { where native antibodies are not available } \\
\text { Use of affinity tags that have high affinity antibod- } \\
\text { ies readily available } \\
\text { Library-independent method allows for true } \\
\text { genome-wide high-throughput capability } \\
\text { Proteins purified in native form }\end{array}$ & $\begin{array}{l}\text { Introduction of affinity tag requires a genetically } \\
\text { tractable virus. } \\
\text { Affinity tag may interfere with virus function and } \\
\text { protein folding } \\
\text { Cell lysis and affinity purification may prevent the } \\
\text { detection of low avidity and transient interac- } \\
\text { tions. } \\
\text { False positives due to co-isolation of non-specifi- } \\
\text { cally bound proteins }\end{array}$ \\
\hline Cross-linked mass spectrometry & $\begin{array}{l}\text { Identification of low avidity and transient interac- } \\
\text { tions } \\
\text { Enrichment and quantitation using trifunctional } \\
\text { cross-linkers } \\
\text { Library-independent method allows for true } \\
\text { genome-wide high-throughput capability } \\
\text { Can gain additional structural information about } \\
\text { binding site }\end{array}$ & $\begin{array}{l}\text { Requires specialised software to identify cross- } \\
\text { linked peptides } \\
\text { Requires the presence of residues susceptible to } \\
\text { cross-linking on the surface of the virus and } \\
\text { receptor } \\
\text { Detected proteins may not be functional receptors } \\
\text { in vivo }\end{array}$ \\
\hline
\end{tabular}


these need to be narrowed down in further validation studies. The choice of validation method depends on the initial identification method. Often orthogonal experiments are used, e.g., proteomic approaches are used to validate results from genomic approaches and vice versa. However, several other approaches can be used to validate virus receptors, such as, competition assays [134], small molecule inhibition of binding [135], co-localization immunofluorescence microscopy [39], and Förster resonance energy transfer assays [136].

In summary, receptor identification is seldom a straightforward process. Therefore, a one-method-fits-all approach cannot be adopted for receptor identification. More commonly, receptors are identified using a combination of different approaches, which contribute to the overall picture of virus entry.

Acknowledgements Open access funding provided by University of Helsinki including Helsinki University Central Hospital. This project (ViBRANT) has received funding from the European Union's Horizon 2020 Research and Innovation Programme under the Marie Skłodowska-Curie grant agreement number 765042 to SJB. SVB is a fellow of the Doctoral Programme in Integrative Life Science, University of Helsinki.

Funding This study was funded by European Union's Horizon 2020 Research and Innovation Programme under the Marie SkłodowskaCurie grant agreement number 765042 to SJB.

\section{Compliance with ethical standards}

Conflict of interest The authors declare that they have no conflicts of interest.

Open Access This article is licensed under a Creative Commons Attribution 4.0 International License, which permits use, sharing, adaptation, distribution and reproduction in any medium or format, as long as you give appropriate credit to the original author(s) and the source, provide a link to the Creative Commons licence, and indicate if changes were made. The images or other third party material in this article are included in the article's Creative Commons licence, unless indicated otherwise in a credit line to the material. If material is not included in the article's Creative Commons licence and your intended use is not permitted by statutory regulation or exceeds the permitted use, you will need to obtain permission directly from the copyright holder. To view a copy of this licence, visit http://creativecommons.org/licenses/by/4.0/.

\section{References}

1. Helenius A (2018) Virus entry: looking back and moving forward. J Mol Biol 430(13):1853-1862. https://doi.org/10.1016/j. jmb.2018.03.034

2. Yamauchi Y, Greber UF (2016) Principles of virus uncoating: cues and the snooker ball. Traffic 17(6):569-592. https://doi. org/10.1111/tra.12387

3. Kroschewski H, Allison SL, Heinz FX, Mandl CW (2003) Role of heparan sulfate for attachment and entry of tick-borne encephalitis virus. Virology 308(1):92-100. https://doi.org/10.1016/ s0042-6822(02)00097-1
4. Vlasak M, Goester I, Blaas D (2005) Human rhinovirus type 89 variants use heparan sulfate proteoglycan for cell attachment. J Virol 79(10):5963-5970. https://doi.org/10.1128/ Jvi.79.10.5963-5970.2005

5. Neu U, Bauer J, Stehle T (2011) Viruses and sialic acids: rules of engagement. Curr Opin Struct Biol 21(5):610-618. https://doi. org/10.1016/j.sbi.2011.08.009

6. Yamauchi Y, Helenius A (2013) Virus entry at a glance. J Cell Sci 126(6):1289-1295. https://doi.org/10.1242/jcs.119685

7. Matlin KS, Reggio H, Helenius A, Simons K (1981) Infectious entry pathway of influenza-virus in a canine kidney-cell line. J Cell Biol 91(3):601-613. https://doi.org/10.1083/jcb.91.3.601

8. Ploss A, Evans MJ, Gaysinskaya VA, Panis M, You HN, de Jong YP, Rice CM (2009) Human occludin is a hepatitis C virus entry factor required for infection of mouse cells. Nature 457(7231):882-886. https://doi.org/10.1038/nature07684

9. Pileri P, Uematsu Y, Campagnoli S, Galli G, Falugi F, Petracca R, Weiner AJ, Houghton M, Rosa D, Grandi G, Abrignani S (1998) Binding of hepatitis C virus to CD81. Science 282(5390):938-941. https://doi.org/10.1126/scien ce. 282.5390 .938

10. Evans MJ, von Hahn T, Tscherne DM, Syder AJ, Panis M, Wolk B, Hatziioannou T, McKeating JA, Bieniasz PD, Rice CM (2007) Claudin-1 is a hepatitis $C$ virus co-receptor required for a late step in entry. Nature 446(7137):801-805. https://doi. org/10.1038/nature05654

11. Scarselli E, Ansuini H, Cerino R, Roccasecca RM, Acali S, Filocamo G, Traboni C, Nicosia A, Cortese R, Vitelli A (2002) The human scavenger receptor class $\mathrm{B}$ type $\mathrm{I}$ is a novel candidate receptor for the hepatitis C virus. EMBO J 21(19):5017-5025

12. Tatsuo H, Ono N, Tanaka K, Yanagi Y (2000) SLAM (CDw150) is a cellular receptor for measles virus. Nature 406(6798):893-897

13. Noyce RS, Bondre DG, Ha MN, Lin LT, Sisson G, Tsao MS, Richardson CD (2011) Tumor cell marker PVRL4 (nectin 4) is an epithelial cell receptor for measles virus. PLoS Pathog 7(8):e1002240. https://doi.org/10.1371/journal.ppat.1002240

14. Yamamoto S, Fukuhara T, Ono C, Uemura K, Kawachi Y, Shiokawa M, Mori H, Wada M, Shima R, Okamoto T, Hiraga N, Suzuki R, Chayama K, Wakita T, Matsuura Y (2016) Lipoprotein receptors redundantly participate in entry of hepatitis $\mathrm{C}$ virus. PLoS Pathog 12(5):e1005610. https://doi.org/10.1371/journ al.ppat. 1005610

15. Bass DM, Greenberg HB (1992) Strategies for the identification of icosahedral virus receptors. J Clin Invest 89(1):3-9. https:// doi.org/10.1172/JCI115575

16. Colonno RJ, Callahan PL, Long WJ (1986) Isolation of a monoclonal antibody that blocks attachment of the major group of human rhinoviruses. J Virol 57(1):7-12

17. Gaulton GN, Co MS, Royer H-D, Greene MI (1984) Anti-idiotypic antibodies as probes of cell surface receptors. Mol Cell Biochem 65(1):5-21. https://doi.org/10.1007/bf00226015

18. Krah DL, Crowell RL (1982) A solid-phase assay of solubilized HeLa cell membrane receptors for binding group B coxsackieviruses and polioviruses. Virology 118(1):148-156

19. Protopopova EV, Sorokin AV, Konovalova SN, Kachko AV, Netesov SV, Loktev VB (1999) Human laminin binding protein as a cell receptor for the tick-borne encephalitis virus. Zentralblatt für Bakteriologie 289(5):632-638. https://doi.org/10.1016/ S0934-8840(99)80021-8

20. Michalski A, Damoc E, Lange O, Denisov E, Nolting D, Muller M, Viner R, Schwartz J, Remes P, Belford M, Dunyach JJ, Cox J, Horning S, Mann M, Makarov A (2012) Ultra high resolution linear ion trap Orbitrap mass spectrometer (Orbitrap Elite) facilitates top down LC MS/MS and versatile peptide 
fragmentation modes. Mol Cell Proteom. https://doi.org/10.1074/ mcp.o111.013698

21. Han J, Perez JT, Chen C, Li Y, Benitez A, Kandasamy M, Lee Y, Andrade J, tenOever B, Manicassamy B (2018) Genomewide CRISPR/Cas9 screen identifies host factors essential for influenza virus replication. Cell Rep 23(2):596-607. https://doi. org/10.1016/j.celrep.2018.03.045

22. Gilbert LA, Horlbeck MA, Adamson B, Villalta JE, Chen Y, Whitehead EH, Guimaraes C, Panning B, Ploegh HL, Bassik MC, Qi LS, Kampmann M, Weissman JS (2014) Genome-scale CRISPR-mediated control of gene repression and activation. Cell 159(3):647-661. https://doi.org/10.1016/j.cell.2014.09.029

23. Wang H, Russa ML, Qi LS (2016) CRISPR/Cas9 in genome editing and beyond. Annu Rev Biochem 85(1):227-264. https:// doi.org/10.1146/annurev-biochem-060815-014607

24. Cherry S (2009) What have RNAi screens taught us about viralhost interactions? Curr Opin Microbiol 12(4):446-452. https:// doi.org/10.1016/j.mib.2009.06.002

25. Panda D, Cherry S (2012) Cell-based genomic screening: elucidating virus-host interactions. Curr Opin Virol 2(6):784-792. https://doi.org/10.1016/j.coviro.2012.10.007

26. Kilcher S, Mercer J (2014) Next generation approaches to study virus entry and infection. Curr Opin Virol 4:8-14. https://doi. org/10.1016/j.coviro.2013.10.002

27. Mohr SE, Smith JA, Shamu CE, Neumüller RA, Perrimon N (2014) RNAi screening comes of age: improved techniques and complementary approaches. Nat Rev Mol Cell Biol 15(9):591600. https://doi.org/10.1038/nrm3860

28. Xie D, Han L, Luo Y, Liu Y, He S, Bai H, Wang S, Bo X (2015) Exploring the associations of host genes for viral infection revealed by genome-wide RNAi and virus-host protein interactions. Mol BioSyst 11(9):2511-2519. https://doi.org/10.1039/c5mb00309a

29. Mohr S, Bakal C, Perrimon N (2010) Genomic screening with RNAi: results and challenges. Annu Rev Biochem 79:37-64. https://doi.org/10.1146/annurev-biochem-060408-092949

30. Wilson RC, Doudna JA (2013) Molecular mechanisms of RNA interference. Annu Rev Biophys 42(1):217-239. https://doi. org/10.1146/annurev-biophys-083012-130404

31. Isaacs A, Lindenmann J (1957) Virus interference. 1. The interferon. Proc R Soc Ser B-Bio 147(927):258-267. https://doi. org/10.1098/rspb.1957.0048

32. Cherry S (2008) Genomic RNAi screening in Drosophila S2 cells: what have we learned about host-pathogen interactions? Curr Opin Microbiol 11(3):262-270. https://doi.org/10.1016/j. mib.2008.05.007

33. Rose PP, Hanna SL, Spiridigliozzi A, Wannissorn N, Beiting DP, Ross SR, Hardy RW, Bambina SA, Heise MT, Cherry S (2011) Natural resistance-associated macrophage protein is a cellular receptor for sindbis virus in both insect and mammalian hosts. Cell Host Microbe 10(2):97-104. https://doi.org/10.1016/j. chom.2011.06.009

34. Zhang H, Li Y, Wang HB, Zhang A, Chen ML, Fang ZX, Dong XD, Li SB, Du Y, Xiong D, He JY, Li MZ, Liu YM, Zhou AJ, Zhong Q, Zeng YX, Kieff E, Zhang ZQ, Gewurz BE, Zhao B, Zeng MS (2018) Ephrin receptor A2 is an epithelial cell receptor for Epstein-Barr virus entry. Nat Microbiol 3(2):164-171. https ://doi.org/10.1038/s41564-017-0080-8

35. Wang HB, Zhang H, Zhang JP, Li Y, Zhao B, Feng GK, Du Y, Xiong D, Zhong Q, Liu WL, Du H, Li MZ, Huang WL, Tsao SW, Hutt-Fletcher L, Zeng YX, Kieff E, Zeng MS (2015) Neuropilin 1 is an entry factor that promotes EBV infection of nasopharyngeal epithelial cells. Nat Commun 6:6240. https://doi. org/10.1038/ncomms 7240

36. Pannell D, Ellis J (2001) Silencing of gene expression: implications for design of retrovirus vectors. Rev Med Virol 11(4):205-217
37. Herbst F, Ball CR, Tuorto F, Nowrouzi A, Wang W, Zavidij O, Dieter SM, Fessler S, van der Hoeven F, Kloz U, Lyko F, Schmidt M, von Kalle C, Glimm H (2012) Extensive methylation of promoter sequences silences lentiviral transgene expression during stem cell differentiation in vivo. Mol Ther 20(5):10141021. https://doi.org/10.1038/mt.2012.46

38. Li Z, Wei J, Fan Y, Mei X, He Q, Zhang Y, Li T, Long M, Chen J, Liu T, Bao J, Xiang Z, Pan G, Li C, Zhou Z (2018) Baculovirus utilizes cholesterol transporter Niemann-Pick $\mathrm{C} 1$ for host cell entry. bioRxiv. https://doi.org/10.1101/312744

39. Carette JE, Raaben M, Wong AC, Herbert AS, Obernosterer G, Mulherkar N, Kuehne AI, Kranzusch PJ, Griffin AM, Ruthel G, Cin PD, Dye JM, Whelan SP, Chandran K, Brummelkamp TR (2011) Ebola virus entry requires the cholesterol transporter Niemann-Pick C1. Nature 477:340. https://doi.org/10.1038/natur e10348

40. Brass AL, Dykxhoorn DM, Benita Y, Yan N, Engelman A, Xavier RJ, Lieberman J, Elledge SJ (2008) Identification of host proteins required for HIV infection through a functional genomic screen. Science 319(5865):921-926. https://doi.org/10.1126/ science. 1152725

41. Konig R, Zhou YY, Elleder D, Diamond TL, Bonamy GMC, Irelan JT, Chiang CY, Tu BP, De Jesus PD, Lilley CE, Seidel S, Opaluch AM, Caldwell JS, Weitzman MD, Kuhen KL, Bandyopadhyay S, Ideker T, Orth AP, Miraglia LJ, Bushman FD, Young JA, Chanda SK (2008) Global analysis of host-pathogen interactions that regulate early-stage HIV-1 replication. Cell 135(1):49-60. https://doi.org/10.1016/j.cell.2008.07.032

42. Zhou H, Xu M, Huang Q, Gates AT, Zhang XD, Castle JC, Stec E, Ferrer M, Strulovici B, Hazuda DJ, Espeseth AS (2008) Genome-scale RNAi screen for host factors required for HIV replication. Cell Host Microbe 4(5):495-504. https://doi. org/10.1016/j.chom.2008.10.004

43. Schmich F, Szczurek E, Kreibich S, Dilling S, Andritschke D, Casanova A, Low SH, Eicher S, Muntwiler S, Emmenlauer M, Rämö P, Conde-Alvarez R, von Mering C, Hardt W-D, Dehio C, Beerenwinkel N (2015) gespeR: a statistical model for deconvoluting off-target-confounded RNA interference screens. Genome Biol 16(1):220. https://doi.org/10.1186/s13059-015-0783-1

44. Birmingham A, Selfors LM, Forster T, Wrobel D, Kennedy CJ, Shanks E, Santoyo-Lopez J, Dunican DJ, Long A, Kelleher D, Smith Q, Beijersbergen RL, Ghazal P, Shamu CE (2009) Statistical methods for analysis of high-throughput RNA interference screens. Nat Methods 6:569. https://doi.org/10.1038/nmeth.1351

45. Barrows NJ, Le Sommer C, Garcia-Blanco MA, Pearson JL (2010) Factors affecting reproducibility between genome-scale siRNA-based screens. J Biomol Screen 15(7):735-747. https:// doi.org/10.1177/1087057110374994

46. Franceschini A, Meier R, Casanova A, Kreibich S, Daga N, Andritschke D, Dilling S, Rämö P, Emmenlauer M, Kaufmann A, Conde-Álvarez R, Low SH, Pelkmans L, Helenius A, Hardt W-D, Dehio C, von Mering C (2014) Specific inhibition of diverse pathogens in human cells by synthetic microRNA-like oligonucleotides inferred from RNAi screens. Proc Natl Acad Sci 111(12):4548-4553. https://doi.org/10.1073/pnas.1402353111

47. Boutros M, Kiger AA, Armknecht S, Kerr K, Hild M, Koch B, Haas SA, Paro R, Perrimon N, Heidelberg Fly Array C (2004) Genome-wide RNAi analysis of growth and viability in Drosophila cells. Science 303(5659):832-835. https://doi.org/10.1126/ science. 1091266

48. Podder S, Ghosh TC (2011) Insights into the molecular correlates modulating functional compensation between monogenic and polygenic disease gene duplicates in human. Genomics 97(4):200-204. https://doi.org/10.1016/j.ygeno.2011.01.004

49. Knapp B, Rebhan I, Kumar A, Matula P, Kiani NA, Binder M, Erfle H, Rohr K, Eils R, Bartenschlager R, Kaderali L (2011) 
Normalizing for individual cell population context in the analysis of high-content cellular screens. BMC Bioinform 12:485. https ://doi.org/10.1186/1471-2105-12-485

50. Zhang XD, Espeseth AS, Johnson EN, Chin J, Gates A, Mitnaul LJ, Marine SD, Tian J, Stec EM, Kunapuli P, Holder DJ, Heyse JF, Strulovici B, Ferrer M (2008) Integrating experimental and analytic approaches to improve data quality in genome-wide RNAi screens. J Biomol Screen 13(5):378-389. https://doi. org/10.1177/1087057108317145

51. Lee T, Shah C, Xu EY (2007) Gene trap mutagenesis: a functional genomics approach towards reproductive research. MHR 13(11):771-779. https://doi.org/10.1093/molehr/gam069

52. Carette JE, Guimaraes CP, Varadarajan M, Park AS, Wuethrich I, Godarova A, Kotecki M, Cochran BH, Spooner E, Ploegh HL, Brummelkamp TR (2009) Haploid genetic screens in human cells identify host factors used by pathogens. Science 326(5957):1231-1235. https://doi.org/10.1126/science.1178955

53. LaFave MC, Varshney GK, Gildea DE, Wolfsberg TG, Baxevanis AD, Burgess SM (2014) MLV integration site selection is driven by strong enhancers and active promoters. Nucleic Acids Res 42(7):4257-4269. https://doi.org/10.1093/nar/gkt1399

54. Bellen HJ, Levis RW, He Y, Carlson JW, Evans-Holm M, Bae E, Kim J, Metaxakis A, Savakis C, Schulze KL, Hoskins RA, Spradling AC (2011) The Drosophila gene disruption project: progress using transposons with distinctive site specificities. Genetics 188(3):731-743. https://doi.org/10.1534/genetics.111.12699 5

55. Pillay S, Carette JE (2015) Hunting viral receptors using haploid cells. Annu Rev Virol 2(1):219-239. https://doi.org/10.1146/ annurev-virology-100114-055119

56. Pillay S, Meyer NL, Puschnik AS, Davulcu O, Diep J, Ishikawa Y, Jae LT, Wosen JE, Nagamine CM, Chapman MS, Carette JE (2016) An essential receptor for adeno-associated virus infection. Nature 530:108. https://doi.org/10.1038/nature16465

57. Essletzbichler P, Konopka T, Santoro F, Chen D, Gapp BV, Kralovics R, Brummelkamp TR, Nijman SMB, Bürckstümmer T (2014) Megabase-scale deletion using CRISPR/Cas9 to generate a fully haploid human cell line. Genome Res 24(12):2059-2065. https://doi.org/10.1101/gr.177220.114

58. Haft DH, Selengut J, Mongodin EF, Nelson KE (2005) A guild of 45 CRISPR-associated (Cas) protein families and multiple CRISPR/Cas subtypes exist in prokaryotic genomes. PLoS Comput Biol 1(6):e60. https://doi.org/10.1371/journal.pcbi.0010060

59. Doudna JA, Charpentier E (2014) The new frontier of genome engineering with CRISPR-Cas9. Science. https://doi. org/10.1126/science. 1258096

60. Hsu PD, Zhang F (2012) Dissecting neural function using targeted genome engineering technologies. ACS Chem Neurosci 3(8):603-610. https://doi.org/10.1021/cn300089k

61. Cho SW, Kim S, Kim JM, Kim J-S (2013) Targeted genome engineering in human cells with the Cas9 RNA-guided endonuclease. Nat Biotechnol 31:230. https://doi.org/10.1038/nbt.2507

62. Cherry S (2019) Encephalomyocarditis virus entry unveiled. mBio. https://doi.org/10.1128/mbio.00305-19

63. Xiaofei E, Meraner P, Lu P, Perreira JM, Aker AM, McDougall WM, Zhuge RH, Chan GC, Gerstein RM, Caposio P, Yurochko AD, Brass AL, Kowalik TF (2019) OR14I1 is a receptor for the human cytomegalovirus pentameric complex and defines viral epithelial cell tropism. P Natl Acad Sci USA 116(14):70437052. https://doi.org/10.1073/pnas.1814850116

64. Bazzone LE, King M, MacKay CR, Kyawe PP, Meraner P, Lindstrom D, Rojas-Quintero J, Owen CA, Wang JP, Brass AL, Kurt-Jones EA, Finberg RW (2019) A disintegrin and metalloproteinase 9 domain (ADAM9) is a major susceptibility factor in the early stages of encephalomyocarditis virus infection. mBio. https://doi.org/10.1128/mbio.02734-18
65. Baggen J, Thibaut HJ, Hurdiss DL, Wahedi M, Marceau CD, van Vliet ALW, Carette JE, van Kuppeveld FJM (2019) Identification of the cell-surface protease ADAM9 as an entry factor for encephalomyocarditis virus. mBio. https://doi.org/10.1128/ mbio.01780-19

66. Jae LT, Raaben M, Herbert AS, Kuehne AI, Wirchnianski AS, Soh TK, Stubbs SH, Janssen H, Damme M, Saftig P, Whelan SP, Dye JM, Brummelkamp TR (2014) Lassa virus entry requires a trigger-induced receptor switch. Science 344(6191):1506-1510. https://doi.org/10.1126/science. 1252480

67. Staring J, van den Hengel LG, Raaben M, Blomen VA, Carette JE, Brummelkamp TR (2018) KREMEN1 is a host entry receptor for a major group of enteroviruses. Cell Host Microbe 23(5):636643.e635. https://doi.org/10.1016/j.chom.2018.03.019

68. Raaben M, Jae LT, Herbert AS, Kuehne AI, Stubbs SH, Chou Y-y, Blomen VA, Kirchhausen T, Dye JM, Brummelkamp TR, Whelan SP (2017) NRP2 and CD63 are host factors for lujo virus cell entry. Cell Host Microbe 22(5):688-696.e685. https ://doi.org/10.1016/j.chom.2017.10.002

69. Haga K, Fujimoto A, Takai-Todaka R, Miki M, Doan YH, Murakami K, Yokoyama M, Murata K, Nakanishi A, Katayama K (2016) Functional receptor molecules CD300lf and CD300ld within the CD300 family enable murine noroviruses to infect cells. Proc Natl Acad Sci 113(41):E6248-E6255. https://doi. org/10.1073/pnas.1605575113

70. Orchard RC, Wilen CB, Doench JG, Baldridge MT, McCune BT, Lee YC, Lee S, Pruett-Miller SM, Nelson CA, Fremont DH, Virgin HW (2016) Discovery of a proteinaceous cellular receptor for a norovirus. Science 353(6302):933-936. https:// doi.org/10.1126/science.aaf1220

71. Zhang R, Kim AS, Fox JM, Nair S, Basore K, Klimstra WB, Rimkunas R, Fong RH, Lin H, Poddar S, Crowe JE, Doranz BJ, Fremont DH, Diamond MS (2018) Mxra8 is a receptor for multiple arthritogenic alphaviruses. Nature 557(7706):570-574. https://doi.org/10.1038/s41586-018-0121-3

72. Jangra RK, Herbert AS, Li R, Jae LT, Kleinfelter LM, Slough MM, Barker SL, Guardado-Calvo P, Román-Sosa G, Dieterle ME, Kuehne AI, Muena NA, Wirchnianski AS, Nyakatura EK, Fels JM, Ng M, Mittler E, Pan J, Bharrhan S, Wec AZ, Lai JR, Sidhu SS, Tischler ND, Rey FA, Moffat J, Brummelkamp TR, Wang Z, Dye JM, Chandran K (2018) Protocadherin-1 is essential for cell entry by New world hantaviruses. Nature 563(7732):559-563. https://doi.org/10.1038/s4158 6-018-0702-1

73. Zhao X, Zhang G, Liu S, Chen X, Peng R, Dai L, Qu X, Li S, Song H, Gao Z, Yuan P, Liu Z, Li C, Shang Z, Li Y, Zhang M, Qi J, Wang H, Du N, Wu Y, Bi Y, Gao S, Shi Y, Yan J, Zhang Y, Xie Z, Wei W, Gao GF (2019) Human neonatal Fc receptor is the cellular uncoating receptor for enterovirus B. Cell 177(6):15531565.e1516. https://doi.org/10.1016/j.cell.2019.04.035

74. Karakus U, Thamamongood T, Ciminski K, Ran W, Günther SC, Pohl MO, Eletto D, Jeney C, Hoffmann D, Reiche S, Schinköthe J, Ulrich R, Wiener J, Hayes MGB, Chang MW, Hunziker A, Yángüez E, Aydillo T, Krammer F, Oderbolz J, Meier M, Oxenius A, Halenius A, Zimmer G, Benner C, Hale BG, García-Sastre A, Beer M, Schwemmle M, Stertz S (2019) MHC class II proteins mediate cross-species entry of bat influenza viruses. Nature 567(7746):109-112. https://doi.org/10.1038/s41586-019-0955-3

75. Feng M, Kong XS, Zhang JJ, Xu WF, Wu XF (2018) Identification of a novel host protein SINAL10 interacting with GP64 and its role in Bombyx mori nucleopolyhedrovirus infection. Virus Res 247:102-110. https://doi.org/10.1016/j.virusres.2018.02.005

76. Vanarsdall AL, Pritchard SR, Wisner TW, Liu J, Jardetzky TS, Johnson DC (2018) CD147 promotes entry of pentamer-expressing human cytomegalovirus into epithelial and endothelial cells. MBio 9(3):19. https://doi.org/10.1128/mbio.00781-18 
77. Das S, Laxminarayana SV, Chandra N, Ravi V, Desai A (2009) Heat shock protein 70 on Neuro2a cells is a putative receptor for Japanese encephalitis virus. Virology 385(1):47-57. https://doi. org/10.1016/j.virol.2008.10.025

78. Cao W, Henry MD, Borrow P, Yamada H, Elder JH, Ravkov EV, Nichol ST, Compans RW, Campbell KP, Oldstone MBA (1998) Identification of $\alpha$-dystroglycan as a receptor for lymphocytic choriomeningitis virus and lassa fever virus. Science 282(5396):20792081. https://doi.org/10.1126/science.282.5396.2079

79. Martinez-Martin N, Marcandalli J, Huang CS, Arthur CP, Perotti M, Foglierini M, Ho HD, Dosey AM, Shriver S, Payandeh J, Leitner A, Lanzavecchia A, Perez L, Ciferri C (2018) An unbiased screen for human cytomegalovirus identifies neuropilin-2 as a central viral receptor. Cell 174(5):1158. https://doi. org/10.1016/j.cell.2018.06.028

80. Radoshitzky SR, Abraham J, Spiropoulou CF, Kuhn JH, Nguyen D, Li W, Nagel J, Schmidt PJ, Nunberg JH, Andrews NC, Farzan M, Choe H (2007) Transferrin receptor 1 is a cellular receptor for New World haemorrhagic fever arenaviruses. Nature 446:92. https://doi.org/10.1038/nature05539

81. Negrete OA, Levroney EL, Aguilar HC, Bertolotti-Ciarlet A, Nazarian R, Tajyar S, Lee B (2005) EphrinB2 is the entry receptor for Nipah virus, an emergent deadly paramyxovirus. Nature 436:401. https://doi.org/10.1038/nature03838

82. Mukherjee S, Sengupta N, Chaudhuri A, Akbar I, Singh N, Chakraborty S, Suryawanshi AR, Bhattacharyya A, Basu A (2018) PLVAP and GKN3 are two critical host cell receptors which facilitate Japanese encephalitis virus entry into neurons. Sci Rep. https://doi.org/10.1038/s41598-018-30054-z

83. Frei AP, Moest H, Novy K, Wollscheid B (2013) Ligand-based receptor identification on living cells and tissues using TRICEPS. Nat Protoc 8(7):1321-1336. https://doi.org/10.1038/nprot.2013.072

84. Munoz DM, Cassiani PJ, Li L, Billy E, Korn JM, Jones MD, Golji J, Ruddy DA, Yu K, McAllister G, DeWeck A, Abramowski D, Wan J, Shirley MD, Neshat SY, Rakiec D, de Beaumont R, Weber O, Kauffmann A, McDonald ER 3rd, Keen N, Hofmann F, Sellers WR, Schmelzle T, Stegmeier F, Schlabach MR (2016) CRISPR screens provide a comprehensive assessment of cancer vulnerabilities but generate false-positive hits for highly amplified genomic regions. Cancer Discov 6(8):900-913. https://doi. org/10.1158/2159-8290.CD-16-0178

85. Yilmaz A, Peretz M, Aharony A, Sagi I, Benvenisty N (2018) Defining essential genes for human pluripotent stem cells by CRISPR-Cas9 screening in haploid cells. Nat Cell Biol 20(5):610-619. https://doi.org/10.1038/s41556-018-0088-1

86. Wang T, Wei JJ, Sabatini DM, Lander ES (2014) Genetic screens in human cells using the CRISPR-Cas9 system. Science 343(6166):80-84. https://doi.org/10.1126/science.1246981

87. Pattanayak V, Lin S, Guilinger JP, Ma E, Doudna JA, Liu DR (2013) High-throughput profiling of off-target DNA cleavage reveals RNA-programmed Cas9 nuclease specificity. Nat Biotechnol 31:839. https://doi.org/10.1038/nbt.2673

88. Smith I, Greenside PG, Natoli T, Lahr DL, Wadden D, Tirosh I, Narayan R, Root DE, Golub TR, Subramanian A, Doench JG (2017) Evaluation of RNAi and CRISPR technologies by largescale gene expression profiling in the connectivity map. PLoS Biol 15(11):e2003213-e2003213. https://doi.org/10.1371/journ al.pbio. 2003213

89. Fu Y, Sander JD, Reyon D, Cascio VM, Joung JK (2014) Improving CRISPR-Cas nuclease specificity using truncated guide RNAs. Nat Biotechnol 32(3):279-284. https://doi.org/10.1038/nbt.2808

90. Ran FA, Hsu Patrick D, Lin C-Y, Gootenberg Jonathan S, Konermann S, Trevino AE, Scott David A, Inoue A, Matoba S, Zhang Y, Zhang F (2013) Double nicking by RNA-guided CRISPR Cas9 for enhanced genome editing specificity. Cell 154(6):1380 1389. https://doi.org/10.1016/j.cell.2013.08.021
91. Dianov GL, Hubscher U (2013) Mammalian base excision repair: the forgotten archangel. Nucleic Acids Res 41(6):3483-3490. https://doi.org/10.1093/nar/gkt076

92. Guilinger JP, Thompson DB, Liu DR (2014) Fusion of catalytically inactive Cas9 to FokI nuclease improves the specificity of genome modification. Nat Biotechnol 32:577. https://doi. org/10.1038/nbt.2909

93. Kleinstiver BP, Pattanayak V, Prew MS, Tsai SQ, Nguyen NT, Zheng Z, Joung JK (2016) High-fidelity CRISPR-Cas9 nucleases with no detectable genome-wide off-target effects. Nature 529:490. https://doi.org/10.1038/nature16526

94. Lee JK, Jeong E, Lee J, Jung M, Shin E, Kim Y-h, Lee K, Jung I, Kim D, Kim S, Kim J-S (2018) Directed evolution of CRISPR-Cas9 to increase its specificity. Nat Commun 9(1):3048. https://doi.org/10.1038/s41467-018-05477-x

95. Slaymaker IM, Gao L, Zetsche B, Scott DA, Yan WX, Zhang F (2016) Rationally engineered Cas9 nucleases with improved specificity. Science (New York, NY) 351(6268):84-88. https:// doi.org/10.1126/science.aad5227

96. Kawano Y, Yoshida T, Hieda K, Aoki J, Miyoshi H, Koyanagi Y (2004) A lentiviral cDNA library employing lambda recombination used to clone an inhibitor of human immunodeficiency virus type 1-induced cell death. J Virol 78(20):11352-11359. https://doi.org/10.1128/JVI.78.20.11352-11359.2004

97. Ohara O, Temple G (2001) Directional cDNA library construction assisted by the in vitro recombination reaction. Nucleic Acids Res 29(4):E22-E22

98. Efstratiadis A, Maniatis T, Kafatos FC, Jeffrey A, Vournakis JN (1975) Full length and discrete partial reverse transcripts of globin and chorion mRNAs. Cell 4(4):367-378

99. Sigoillot FD, King RW (2011) Vigilance and validation: keys to success in RNAi screening. ACS Chem Biol 6(1):47-60. https://doi.org/10.1021/cb100358f

100. Wellenreuther R, Schupp I, Poustka A, Wiemann S, The German c DNAC (2004) SMART amplification combined with cDNA size fractionation in order to obtain large full-length clones. BMC Genom 5(1):36. https://doi. org/10.1186/1471-2164-5-36

101. Malboeuf CM, Isaacs SJ, Tran NH, Kim B (2001) Thermal effects on reverse transcription: improvement of accuracy and processivity in cDNA synthesis. BioTechniques 30(5):10741078. https://doi.org/10.2144/01305rr06

102. Lasswitz L, Chandra N, Arnberg N, Gerold G (2018) Glycomics and proteomics approaches to investigate early adenovirus-host cell interactions. J Mol Biol 430(13):1863-1882. https://doi. org/10.1016/j.jmb.2018.04.039

103. Tuve S, Wang H, Jacobs JD, Yumul RC, Smith DF, Lieber A (2008) Role of cellular heparan sulfate proteoglycans in infection of human adenovirus serotype 3 and 35. PLoS Pathog 4(10):e1000189. https://doi.org/10.1371/journal.ppat.1000189

104. Yu X, Xu D, Cheng Q (2006) Label-free detection methods for protein microarrays. Proteomics 6(20):5493-5503. https://doi. org/10.1002/pmic.200600216

105. Zhu H, Bilgin M, Bangham R, Hall D, Casamayor A, Bertone P, Lan N, Jansen R, Bidlingmaier S, Houfek T, Mitchell T, Miller P, Dean RA, Gerstein M, Snyder M (2001) Global analysis of protein activities using proteome chips. Science 293(5537):21012105. https://doi.org/10.1126/science.1062191

106. Gupta S, Manubhai KP, Kulkarni V, Srivastava S (2016) An overview of innovations and industrial solutions in protein microarray technology. Proteomics 16(8):1297-1308. https:// doi.org/10.1002/pmic.201500429

107. Bushell KM, Sollner C, Schuster-Boeckler B, Bateman A, Wright GJ (2008) Large-scale screening for novel low-affinity extracellular protein interactions. Genome Res 18(4):622-630. https:// doi.org/10.1101/gr.7187808 
108. Ramachandran N, Raphael JV, Hainsworth E, Demirkan G, Fuentes MG, Rolfs A, Hu Y, LaBaer J (2008) Next-generation high-density self-assembling functional protein arrays. Nat Methods 5(6):535-538. https://doi.org/10.1038/nmeth.1210

109. Glick Y, Ben-Ari Y, Drayman N, Pellach M, Neveu G, Boonyaratanakornkit J, Avrahami D, Einav S, Oppenheim A, Gerber D (2016) Pathogen receptor discovery with a microfluidic human membrane protein array. Proc Natl Acad Sci USA 113(16):43444349. https://doi.org/10.1073/pnas.1518698113

110. Lum KK, Cristea IM (2016) Proteomic approaches to uncovering virus-host protein interactions during the progression of viral infection. Expert Rev Proteom 13(3):325-340. https://doi. org/10.1586/14789450.2016.1147353

111. Cristea IM, Williams R, Chait BT, Rout MP (2005) Fluorescent proteins as proteomic probes. Mol Cell Proteom MCP 4(12):19331941. https://doi.org/10.1074/mcp.M500227-MCP200

112. Reitsma JM, Savaryn JP, Faust K, Sato H, Halligan BD, Terhune SS (2011) Antiviral inhibition targeting the HCMV kinase pUL97 requires pUL27-dependent degradation of Tip60 acetyltransferase and cell-cycle arrest. Cell Host Microbe 9(2):103114. https://doi.org/10.1016/j.chom.2011.01.006

113. Poyomtip T, Hodge K, Matangkasombut P, Sakuntabhai A, Pisitkun T, Jirawatnotai S, Chimnaronk S (2016) Development of viable TAP-tagged dengue virus for investigation of host-virus interactions in viral replication. J Gen Virol 97(3):646-658. https ://doi.org/10.1099/jgv.0.000371

114. Rigaut G, Shevchenko A, Rutz B, Wilm M, Mann M, Seraphin B (1999) A generic protein purification method for protein complex characterization and proteome exploration. Nat Biotechnol 17(10):1030-1032. https://doi.org/10.1038/13732

115. Clegg C, Hayes D (1974) Identification of neighbouring proteins in the ribosomes of Escherichia coli. A topographical study with the cross-linking reagent dimethyl suberimidate. Eur J Biochem 42(1):21-28

116. Yu C, Huang L (2018) Cross-linking mass spectrometry: an emerging technology for interactomics and structural biology. Anal Chem 90(1):144-165. https://doi.org/10.1021/acs.analchem.7b04431

117. Sinz A (2006) Chemical cross-linking and mass spectrometry to map three-dimensional protein structures and protein-protein interactions. Mass Spectrom Rev 25(4):663-682. https://doi. org/10.1002/mas.20082

118. Tremblay T-L, Hill JJ (2017) Biotin-transfer from a trifunctional crosslinker for identification of cell surface receptors of soluble protein ligands. Sci Rep. https://doi.org/10.1038/srep46574

119. Tan D, Li Q, Zhang M-J, Liu C, Ma C, Zhang P, Ding Y-H, Fan S-B, Tao L, Yang B, Li X, Ma S, Liu J, Feng B, Liu X, Wang H-W, He S-M, Gao N, Ye K, Dong M-Q, Lei X (2016) Trifunctional cross-linker for mapping protein-protein interaction networks and comparing protein conformational states. eLife 5:e12509. https://doi.org/10.7554/elife.12509

120. Frei AP, Jeon OY, Kilcher S, Moest H, Henning LM, Jost C, Pluckthun A, Mercer J, Aebersold R, Carreira EM, Wollscheid B (2012) Direct identification of ligand-receptor interactions on living cells and tissues. Nat Biotechnol 30(10):997-1001. https ://doi.org/10.1038/nbt.2354

121. Hsiao JC, Chung CS, Chang W (1999) Vaccinia virus envelope D8L protein binds to cell surface chondroitin sulfate and mediates the adsorption of intracellular mature virions to cells. J Virol 73(10):8750-8761

122. Mercer J, Helenius A (2008) Vaccinia virus uses macropinocytosis and apoptotic mimicry to enter host cells. Science 320(5875):531-535. https://doi.org/10.1126/science.1155164

123. Chiu WL, Lin CL, Yang MH, Tzou DL, Chang W (2007) Vaccinia virus 4c (A26L) protein on intracellular mature virus binds to the extracellular cellular matrix laminin. J Virol 81(5):21492157. https://doi.org/10.1128/JVI.02302-06
124. Yilmaz S, Shiferaw GA, Rayo J, Economou A, Martens L, Vandermarliere E (2018) Cross-linked peptide identification: a computational forest of algorithms. Mass Spectrom Rev 37(6):738749. https://doi.org/10.1002/mas.21559

125. Sims D, Mendes-Pereira AM, Frankum J, Burgess D, Cerone M-A, Lombardelli C, Mitsopoulos C, Hakas J, Murugaesu N, Isacke CM, Fenwick K, Assiotis I, Kozarewa I, Zvelebil M, Ashworth A, Lord CJ (2011) High-throughput RNA interference screening using pooled shRNA libraries and next generation sequencing. Genome Biol 12(10):R104. https://doi.org/10.1186/ gb-2011-12-10-r104

126. Fessler E, Jae LT (2018) Haploid screening for the identification of host factors in virus infection. Methods Mol Biol (Clifton, NJ) 1836:121-137. https://doi.org/10.1007/978-1-4939-8678-1_6

127. Joung J, Konermann S, Gootenberg JS, Abudayyeh OO, Platt RJ, Brigham MD, Sanjana NE, Zhang F (2017) Genome-scale CRISPR-Cas9 knockout and transcriptional activation screening. Nat Protoc 12(4):828-863. https://doi.org/10.1038/nprot.2017.016

128. Henser-Brownhill T, Monserrat J, Scaffidi P (2018) Generation of an arrayed CRISPR-Cas9 library targeting epigenetic regulators: from high-content screens to in vivo assays. Epigenetics 12(12):1065-1075. https://doi.org/10.1080/15592 294.2017.1395121

129. Liu G, Wang X, Liu Y, Zhang M, Cai T, Shen Z, Jia Y, Huang Y (2017) Arrayed mutant haploid embryonic stem cell libraries facilitate phenotype-driven genetic screens. Nucleic Acids Res 45(22):e180-e180. https://doi.org/10.1093/nar/gkx857

130. Shayakhmetov DM, Gaggar A, Ni S, Li Z-Y, Lieber A (2005) Adenovirus binding to blood factors results in liver cell infection and hepatotoxicity. J Virol 79(12):7478-7491. https://doi. org/10.1128/JVI.79.12.7478-7491.2005

131. Waddington SN, McVey JH, Bhella D, Parker AL, Barker K, Atoda H, Pink R, Buckley SM, Greig JA, Denby L, Custers J, Morita T, Francischetti IM, Monteiro RQ, Barouch DH, van Rooijen N, Napoli C, Havenga MJ, Nicklin SA, Baker AH (2008) Adenovirus serotype 5 hexon mediates liver gene transfer. Cell 132(3):397-409. https://doi.org/10.1016/j.cell.2008.01.016

132. Trybala E, Roth A, Johansson M, Liljeqvist JA, Rekabdar E, Larm $\mathrm{O}$, Bergstrom T (2002) Glycosaminoglycan-binding ability is a feature of wild-type strains of herpes simplex virus type 1. Virology 302(2):413-419. https://doi.org/10.1006/viro.2002.1639

133. Karelehto E, Cristella C, Yu X, Sridhar A, Hulsdouw R, de Haan K, van Eijk H, Koekkoek S, Pajkrt D, de Jong MD, Wolthers KC (2018) Polarized entry of human parechoviruses in the airway epithelium. Front Cell Infect Microbiol 8:294. https://doi. org/10.3389/fcimb.2018.00294

134. Jonsson N, Gullberg M, Israelsson S, Lindberg AM (2009) A rapid and efficient method for studies of virus interaction at the host cell surface using enteroviruses and real-time PCR. Virol J 6:217-217. https://doi.org/10.1186/1743-422X-6-217

135. Kwon Y-J, Heo J, Wong HEE, Cruz DJM, Velumani S, da Silva CT, Mosimann ALP, Duarte dos Santos CN, Freitas-Junior LH, Fink K (2014) Kinome siRNA screen identifies novel cell-type specific dengue host target genes. Antiviral Res 110:20-30. https ://doi.org/10.1016/j.antiviral.2014.07.006

136. Helbig KJ, Eyre NS, Yip E, Narayana S, Li K, Fiches G, McCartney EM, Jangra RK, Lemon SM, Beard MR (2011) The antiviral protein viperin inhibits hepatitis $C$ virus replication via interaction with nonstructural protein 5A. Hepatology (Baltimore, MD) 54(5):1506-1517. https://doi.org/10.1002/hep.24542

Publisher's Note Springer Nature remains neutral with regard to jurisdictional claims in published maps and institutional affiliations. 